\title{
Screening for Chromosomal Abnormalities by First Trimester Combined Screening and Noninvasive Prenatal Testing
}

\section{Screening auf Chromosomenstörungen mittels Ersttrimester-Screening und non-invasive prenatal Testing}

Authors

Affiliations
K. O. Kagan ${ }^{1}$, M. Hoopmann' ${ }^{1}$ R. Hammer ${ }^{2}$, R. Stressig ${ }^{2}$, P. Kozlowski ${ }^{2}$

Department of Obstetrics and Gynaecology, University of Tuebingen, Tübingen

Praenatal Medicine and Genetics, praenatal.de, Düsseldorf

\author{
Key words \\ - first trimester \\ - trisomy \\ nuchal translucency \\ NIPT
}

received $\quad 15.12 .2013$

accepted 28.7.2014

\section{Bibliography}

DOI http://dx.doi.org/

10.1055/s-0034-1385059

Published online: September 25, 2014

Ultraschall in Med 2015; 36 :

40-46 @ Georg Thieme Verlag KG Stuttgart · New York .

ISSN 0172-4614

\section{Correspondence}

Prof. Karl Oliver Kagan

Department of Obstetrics and

Gynaecology, University of

Tuebingen

Calwer Straße 7

72076 Tuebingen

Germany

Tel.: ++ 49/1 71/7 714825

Fax: ++ 49/70 71/295619

kokagan@gmx.de

\section{Abstract \\ V}

Purpose: To examine combined first trimester screening (FTS), noninvasive prenatal testing (NIPT) and a two-step policy that combines FTS and NIPT in screening for aneuploidy.

Materials and Methods: Retrospective study involving 21052 pregnancies where FTS was performed at the Praxis Praenatal.de in Duesseldorf, Germany. In each case, the sum risk of trisomy 21, 18 and 13 was computed. We assumed that NIPT detects $99 \%, 98 \%, 90 \%$ and $99 \%$ of cases with trisomy 21, 18, 13 and sex chromosomal abnormalities and that the false-positive rate is $0.5 \%$. The following screening policies were examined: NIPT or FTS with sum risk cut-offs of 1 in 50 and 1 in 250 in all patients or a two-step-policy with FTS in all patients followed by NIPT in the intermediate sum risk group. For the intermediate risk group, sum risk cut-offs of 1 in 50 and 1 in 1000 and 1 in 150 and 1 in 500 were used.

Results: There were $127,34,13$ and 15 pregnancies with trisomy 21, 18, 13 and sex chromosomal abnormalities. 23 fetuses had other chromosomal abnormalities with an increased risk for adverse outcome that are not detectable by NIPT. 20840 pregnancies were classified as normal as anteand postnatal examinations did not show any signs of clinically significant chromosomal abnormalities. FTS with a sum risk cut-off of 1 in 50 and 1 in 250 detects $81 \%$ and $91 \%$ for all aneuploidies. NIPT detects $88 \%$ of the respective pregnancies. The 2-step approach with sum risk cutoffs of 1 in 50 and 1 in 1000 detects $94 \%$ of all aneuploidies. With sum risk cut-offs of 1 in 150 and 1 in 500 , the detection rate is $93 \%$.

Conclusion: A 2-step policy with FTS for all patients and NIPT in the intermediate risk group results in the highest detection rate of all aneuploidies.

\section{Zusammenfassung \\ $\nabla$}

Ziel: Beurteilung der Testgüte unterschiedlicher Screening-Ansätze im Aneuploidie-Screening im ersten Trimenon, die auf dem kombinierten Ersttrimester-Screening (ETS), dem non-invasiven prenatal testing (NIPT) und der Kombination beider Ansätze basieren.

Material und Methoden: Retrospektive Studie mit 21052 Schwangerschaften, die in der Praxis Pränatal.de in Düsseldorf untersucht wurden. In jeder Schwangerschaft wurde das Summenrisiko für Trisomie 21, 18 und 13 berechnet. Wir nahmen an, dass NIPT 99\%, 98\%, 90\% und 99\% der Schwangerschaften mit Trisomie 21, 18, 13 und gonosomale Aberrationen erkennt und dass die Falsch-Positivrate bei 0,5\% liegt. Es wurden folgende Optionen untersucht: für alle Patientinnen NIPT oder ETS (Summenrisiko Cut-off 1 in 50 oder 1 in 250) oder ein 2-Stufen-Ansatz mit ETS für alle Patientinnen und NIPT bei intermediärem Summenrisiko. Als Summenrisiko Cut-offs wurden dabei 1 in 50 und 1 in 1000 sowie 1 in 150 und 1 in 500 verwendet.

Ergebnisse: Trisomien 21, 18, 13 und gonosomale Aberrationen wurden bei 127, 34, 13 und 15 Schwangerschaften gefunden. 23 Feten hatten andere Chromosomenstörungen mit einem adversen Outcome, die methodenbedingt derzeit nicht durch NIPT erkannt werden können. Bei 20840 Schwangerschaften gab es keinen Hinweis auf eine klinisch relevante Chromosomenstörung. ETS mit einem Summenrisiko Cut-off von 1 in 50 und 1 in 250 würde $81 \%$ und $91 \%$ aller Aneuploidien erkennen. Der alleinige NIPT-Ansatz würde zu einer Detektionsrate von $88 \%$ aller Aneuploidien führen. Der 2-Stufen-Ansatz mit 1 in 50 und 1 in 1000 als Summenrisiko Cut-off hätte $94 \%$ aller Aneuploidien erkannt. Bei einem Summenrisiko Cut-off von 1 in 150 und 1 in $50093 \%$ erkannt worden. 
Schlussfolgerung: Die Kombination aus ETS und NIPT in der intermediären Risikogruppe führt zu der höchsten Erkennungsrate von aneuploiden Feten.

\section{Introduction}

In many countries, first trimester combined screening based on maternal and gestational age, fetal nuchal translucency (NT), free beta-hCG and PAPP-A is considered to be the gold standard in screening for trisomy 21 , with a detection rate of about $90 \%$ and a false-positive rate of $3-5 \%$ [ $1-3]$. In contrast, noninvasive prenatal testing (NIPT) provides much higher detection rates of about $99 \%$ for trisomy 21 screening, with a false-positive rate of $0.1 \%$ [ $4-8$ ]. In the long term, it is expected that NIPT will be the main method of screening. However, NIPT is currently still too expensive to offer it to all patients [6].

It could become cost-effective if first trimester screening, which is substantially cheaper and widely available, is combined with NIPT [9]. Nicolaides et al. proposed a contingent approach in which first trimester combined risk assessment is done first and NIPT is only offered if the risk of trisomies is higher than 1 in 3000 [10]. Chorionic villus sampling is only carried out in those with a positive NIPT result and, if NIPT testing fails to provide a result, in those with a combined test risk of 1 in 100 or higher. Such a policy would lead to diagnosis of $96.9 \%$ of cases of trisomy 21 and require invasive testing in $0.39 \%$ of the total population. However, this approach only focuses on trisomy 21 . In a recent series of 96416 karyotype analyses, Grati et al. emphasized that if screening focuses only on trisomy 21 , about half the chromosomal abnormalities would be missed [11]. Even if screening is extended to trisomy 13,18 and sex chromosomal abnormalities, there will still be some cases with other chromosomal anomalies, such as triploidy or structural defects, that are associated with an adverse outcome.

As most aneuploid fetuses have an increased first trimester risk of trisomy due to increased NT thickness or low PAPP-A levels, a contingent screening strategy including first trimester combined screening and NIPT seems reasonable. Different combinations, such as first trimester combined screening with karyotyping in the high risk group and NIPT in the intermediate risk group, or first trimester combined screening and NIPT if the risk surpasses a certain cut-off, are also possible.

In this study, we examine the performance and the respective costs of five different contingent screening policies that combine first trimester combined screening with NIPT.

\section{Methods}

\section{$\nabla$}

This is a retrospective study involving pregnancies in which first trimester combined screening was performed at the Praxis Praenatal.de in Duesseldorf, Germany between January 2000 and September 2012. Praxis Praenatal is a large private practice with about 15000 patients a year.

First trimester screening was performed by a combination of maternal age, fetal NT thickness and maternal serum free $\beta$-hCG and PAPP-A in a one-stop clinic for first trimester assessment of risk (OSCAR) at $11^{+0}-13^{+6}$ weeks of gestation $[12,13]$. Transabdominal or transvaginal ultrasound examination was performed to diagnose any major fetal defects and to measure the crown-rump length (CRL) and the fetal NT thickness. The pregnancy was dated according to the last menstrual period, but if the dates were uncertain or the estimated gestation by CRL was discordant by more than seven days from the estimated gestation from dates, the CRL was used to date the pregnancy. Automated machines that provide reproducible results within 30 minutes were used to measure PAPP-A and free $\beta$-hCG (Kryptor system, ThermoFischer AG, Berlin/ Germany).

Maternal demographic characteristics, ultrasonographic measurements and biochemical results were recorded in a computer database. Karyotyping was performed on maternal request, either because of an increased risk of trisomies, or due to maternal anxiety. Details on pregnancy outcomes were added to the database as soon as they became available.

In Germany, all neonates are seen by a pediatrician after birth and at least six times within the first year of life. If a chromosomal abnormality is suspected, karyotyping is performed. If a child develops normally, no further genetic examination is carried out. We only included data of fetuses that were born at least a year ago to allow sufficient time for postnatal follow-up examinations.

\section{Statistical analysis}

For each pregnancy, the risk of trisomy 21,18 and 13 was calculated based on the maternal and gestational age-related risk, the NT thickness and the serum levels of free beta-hCG and PAPP-A [12-16]. The sum risk of trisomy was calculated as the sum of the risk of trisomy 21, 18 and 13.

We examined five different first trimester screening policies for chromosomal abnormalities:

1. Screening for chromosomal abnormalities in all patients by the first trimester combined test with a sum risk cut-off of 1 in 250 and subsequent karyotyping in the screen positive group.

2. Screening for chromosomal abnormalities in all patients by the first trimester combined test with a sum risk cut-off of 1 in 50 and subsequent karyotyping in the screen positive group.

3. Contingent screening with first trimester combined screening in all women and NIPT in the intermediate risk group.

First line screening for chromosomal abnormalities is performed using the first trimester combined test for all patients. The sum risk is classified as high risk (1 in 50 or higher), intermediate risk (between 1 in 51 and 1 in 1000) or low risk (1 in 1001 or lower). In the low risk group, no further screening examinations are carried out. In the intermediate group, NIPT is performed with an estimated screening performance. If NIPT is uninformative, the case is classified as screen positive and karyotyping is performed.

In summary, karyotyping is offered in the screen positive group after combined screening, the screen positive cases after NIPT, and the cases with uninformative NIPT results.

4. Same as policy 4) but with cut-offs of 1 in 150 and 1 in 500 . 5. First line screening for chromosomal abnormalities by NIPT. In this group, NIPT is carried out for all patients with an estimated screening performance. In cases with uninformative NIPT results, we assumed that combined screening was performed with a risk cut-off of 1 in 50 . According to policy 2, this cut-off corresponds to a false-positive rate of $2.3 \%$. 
In summary, karyotyping is offered in the screen positive cases after NIPT, or in those cases with a sum risk after combined screening of 1 in 50 or more following an informative NIPT result. We assumed that NIPT provides detection rates of $99 \%$ for trisomy $21,98 \%$ for trisomy $18,90 \%$ for trisomy 13 and $99 \%$ for sex chromosomal abnormalities [5]. The overall false-positive rate was set at $0.5 \%$. In addition, we assumed that $3 \%$ of the NIPT results are uninformative and for simplification, we presumed that all of these cases are euploid [17]. The estimated number of screen positive cases was rounded to the nearest whole number. Detection and false-positive rates were calculated by taking the proportions with risks above a certain risk threshold. To estimate the costs of each policy, we assumed that first trimester combined screening costs $€ 150$, NIPT $€ 500$ and karyotyping $€ 1000$.

\section{Results}

The search of the database identified 21829 cases. 777 (3.6\%) cases were excluded from the further analysis: 648 cases were lost to follow-up, and in 129 cases, the pregnancy resulted in an intrauterine death without having obtained the karyotype.

In 20803 (98.8\%) cases the karyotype was normal. An abnormal karyotype was found in 249 (1.2\%) pregnancies. In 37 (14.9\%) cases, there was an inherited balanced rearrangement or a normal variant. These cases were grouped together with the normal cases for further analysis. There were 127 (51.0\%), 34 (13.7\%) and
13 (5.2\%) cases with trisomy 21, 18 and 13, respectively. 9 (3.6\%) fetuses had Turner syndrome and 6 (2.4\%) had other gonosomal abnormalities. In 23 (9.2\%) cases, an atypical chromosomal abnormality with an increased risk of adverse outcome was found ( $\bullet$ Table 1). Thus, your study population consisted of 21052 cases: 20840 normal pregnancies and 212 pregnancies with a clinically relevant chromosomal abnormality.

According to the maternal and gestational age distribution in our study population, 107 (95\% prediction interval 87 -127) cases of trisomy 21 were expected.

- Table 2 summarizes the first trimester screening results. In the normal and in the trisomy 21 group, the median maternal age was 35.1 and 37.6 years, respectively. In the two study groups, the median delta NT was -0.06 and $1.71 \mathrm{~mm}$, the median free beta-hCG was 1.02 and $2.32 \mathrm{MoM}$ and the median PAPP-A was 1.06 and $0.58 \mathrm{MoM}$, respectively. In the atypical cases, the median maternal age was 37.9 years and the median delta NT was $0.18 \mathrm{~mm}$. The median serum levels of free beta-hCG and PAPP-A were $1.37 \mathrm{MoM}$ and $0.51 \mathrm{MoM}$, respectively. $\bullet$ Table 3 shows the distribution of the sum risk in the euploid and in aneuploid pregnancies.

\section{First trimester screening policies}

1. First trimester combined screening with a cut-off of 1 in 250

First trimester combined screening with a risk cut-off of 1 in 250 results in $1813(8.7 \%)$ false-positive cases. Such a policy detects

Table 1 Characteristics of 23 cases with atypical chromosomal abnormalities with an increased risk of adverse outcome.

\begin{tabular}{|c|c|c|c|c|c|c|c|}
\hline final full karyotype & $\begin{array}{l}\text { invasive } \\
\text { test }\end{array}$ & $\begin{array}{l}\text { maternal age } \\
\text { (years) }\end{array}$ & $\begin{array}{l}\text { crown rump } \\
\text { length }(\mathrm{mm})\end{array}$ & $\begin{array}{l}\text { nuchal trans- } \\
\text { lucency } \\
\text { (mm) }\end{array}$ & $\begin{array}{l}\text { free } \\
\text { b-hCG } \\
\text { (MoM) }\end{array}$ & $\begin{array}{l}\text { PAPP-A } \\
\text { (MoM) }\end{array}$ & $\begin{array}{l}\text { Sum risk } \\
\text { for trisomy }\end{array}$ \\
\hline triploidy & CVS & 42.0 & 80.0 & 8.2 & 28.86 & 2.66 & 1 in 2 \\
\hline triploidy & CVS & 29.3 & 58.9 & 10.0 & 5.46 & 0.60 & 1 in 2 \\
\hline triploidy & CVS & 30.3 & 49.2 & 3.1 & 10.31 & 0.45 & 1 in 2 \\
\hline $46, X Y+16$ & $A C$ & 43.7 & 61.4 & 1.9 & 2.06 & 0.16 & 1 in 2 \\
\hline triploidy & CVS & 44.1 & 57.0 & 1.2 & 0.09 & 0.14 & 1 in 4 \\
\hline $47, X Y,+$ mar & CVS & 44.0 & 72.3 & 1.5 & 0.89 & 0.22 & 1 in 9 \\
\hline $\begin{array}{l}\text { 46, XX, del(4)(q?25) de novo.ish del(4) } \\
\text { (idem;q34)(wcp4 + dim, D4S2930 +) }\end{array}$ & CVS & 33.6 & 53.3 & 6.4 & 1.39 & 1.37 & 1 in 12 \\
\hline $47, X Y,+16 / 46, X Y(30 / 30)$ & CVS \& AC & 37.9 & 45.9 & 1.0 & 1.18 & 0.16 & 1 in 13 \\
\hline $\begin{array}{l}\text { 46, XX, del(5)(p15.3?1p14.1 p14.2), } \\
\text { ins }(9 ; 5)(q 31 ; p 15.2 p 14.1 \sim p 14.2 \text { or } \\
p 14.1 \sim p 14.2 p 15.2) \text { de novo }\end{array}$ & CVS & 30.7 & 63.7 & 4.1 & 1.04 & 0.59 & 1 in 15 \\
\hline triploidy & CVS & 36.6 & 47.9 & 1.3 & 0.23 & 0.19 & 1 in 21 \\
\hline $46, X X, i(21)(q 10)$ de novo & CVS \& AC & 25.1 & 72.0 & 4.2 & 2.42 & 1.79 & 1 in 27 \\
\hline $\begin{array}{l}46, X X / 47, X X, \text { ish } r(1) \\
(:: p 11.1->q 21.1::) 28: 7 \text { de novo }\end{array}$ & $A C$ & 40.9 & 61.2 & 1.3 & 3.98 & 0.71 & 1 in 28 \\
\hline triploidy & CVS & 34.5 & 51.0 & 1.6 & 0.07 & 0.16 & 1 in 33 \\
\hline triploidy & CVS & 34.4 & 49.5 & 0.9 & 0.14 & 0.05 & 1 in 34 \\
\hline $\operatorname{mos} 47, \mathrm{XY},+\operatorname{mar}[43] / 46, \mathrm{XY}[57)$ & $A C$ & 44.8 & 75.1 & 2.0 & 1.37 & 0.51 & 1 in 38 \\
\hline $70, X X X X / 68, X X(4 / 21)$ & $A C \& C T$ & 32.9 & 47.2 & 1.0 & 0.17 & 0.27 & 1 in 44 \\
\hline triploidy & CVS & 31.4 & 51.9 & 1.4 & 0.16 & 0.05 & 1 in 57 \\
\hline $\begin{array}{l}47, \mathrm{XY},+\mathrm{ish} \operatorname{dic}(22) \\
\text { (pter q11.2::q11.2 pter) de novo }\end{array}$ & $A C$ & 39.0 & 74.1 & 2.9 & 1.62 & 1.14 & 1 in 72 \\
\hline $47, X Y+\operatorname{der}(16)$ & $A C$ & 40.6 & 71.3 & 2.0 & 3.46 & 1.07 & 1 in 74 \\
\hline triploidy & CVS & 25.0 & 60.0 & 1.8 & 0.03 & 0.04 & 1 in 99 \\
\hline 46, X.ish inv $(X)(p 11.4 q 22 . ? 3)$ de novo & $A C$ & 43.3 & 62.5 & 1.2 & 2.93 & 3.03 & 1 in 496 \\
\hline $\begin{array}{l}\operatorname{mos} 47, X X,+\min (1)(: p 11.1->q 21.1:) \\
{[8] / 46, X X[15] \text { de novo }}\end{array}$ & $A C \& C T$ & 39.5 & 63.2 & 1.6 & 1.35 & 1.38 & 1 in 1368 \\
\hline $46, X X, \operatorname{del}(14)(q 22)$ & $A C$ & 37.9 & 57.0 & 1.1 & 1.59 & 5.18 & 1 in 2004 \\
\hline
\end{tabular}


Table 2 Median maternal age, crown rump length, nuchal translucency thickness and serum marker levels in euploid and aneuploid pregnancies.

\begin{tabular}{|c|c|c|c|c|c|c|}
\hline \multirow{2}{*}{$\begin{array}{l}\text { first trimester } \\
\text { screening parameters }\end{array}$} & \multicolumn{6}{|l|}{ karyotype } \\
\hline & $\begin{array}{l}\text { normal median } \\
\text { (IQR) }\end{array}$ & $\begin{array}{l}\text { T21 median } \\
\text { (IQR) }\end{array}$ & $\begin{array}{l}\text { T18 median } \\
\text { (IQR) }\end{array}$ & $\begin{array}{l}\text { T13 median } \\
\text { (IQR) }\end{array}$ & $\begin{array}{l}\text { sex median } \\
\text { (IQR) }\end{array}$ & $\begin{array}{l}\text { atypical median } \\
\text { (IQR) }\end{array}$ \\
\hline $\begin{array}{l}\text { maternal age } \\
\text { (years) }\end{array}$ & $\begin{array}{l}35.1 \\
(32.2-37.6)\end{array}$ & $\begin{array}{l}37.6 \\
(34.9-39.7)\end{array}$ & $\begin{array}{l}37.1 \\
(35-41.1)\end{array}$ & $\begin{array}{l}33.0 \\
(32.1-37.7)\end{array}$ & $\begin{array}{l}35.3 \\
(32.2-41)\end{array}$ & $\begin{array}{l}37.9 \\
(31.4-42)\end{array}$ \\
\hline $\begin{array}{l}\text { crown rump length } \\
(\mathrm{mm})\end{array}$ & $\begin{array}{l}66.2 \\
(61.5-71.1)\end{array}$ & $\begin{array}{l}66.0 \\
(61.1-70.7)\end{array}$ & $\begin{array}{l}59.1 \\
(54.7-63.2)\end{array}$ & $\begin{array}{l}64.2 \\
(55-66.7)\end{array}$ & $\begin{array}{l}65.9 \\
(59.6-67.5)\end{array}$ & $\begin{array}{l}60.0 \\
(51-71.3)\end{array}$ \\
\hline $\begin{array}{l}\text { nuchal translucency } \\
(\mathrm{mm})\end{array}$ & $\begin{array}{l}1.6 \\
(1.4-1.9)\end{array}$ & $\begin{array}{l}3.4 \\
(2.6-5)\end{array}$ & $\begin{array}{l}4.2 \\
(2.1-6)\end{array}$ & $\begin{array}{l}3.7 \\
(3.3-6.6)\end{array}$ & $\begin{array}{l}4.8 \\
(1.8-8.8)\end{array}$ & $\begin{array}{l}1.6 \\
(1.2-3.1)\end{array}$ \\
\hline $\begin{array}{l}\text { delta nuchal translucency } \\
(\mathrm{mm})\end{array}$ & $\begin{array}{l}-0.06 \\
(-0.29-0.19)\end{array}$ & $\begin{array}{l}1.71 \\
(0.92-3.42)\end{array}$ & $\begin{array}{l}2.57 \\
(0.37-4.65)\end{array}$ & $\begin{array}{l}2.50 \\
(1.67-5.24)\end{array}$ & $\begin{array}{l}3.05 \\
(0.24-7.36)\end{array}$ & $\begin{array}{l}0.18 \\
(-0.24-1.89)\end{array}$ \\
\hline $\begin{array}{l}\text { free beta hCG } \\
\text { (MoM) }\end{array}$ & $\begin{array}{l}1.02 \\
(0.69-1.5)\end{array}$ & $\begin{array}{l}2.32 \\
(1.4-3.34)\end{array}$ & $\begin{array}{l}0.22 \\
(0.13-0.34)\end{array}$ & $\begin{array}{l}0.57 \\
(0.44-0.86)\end{array}$ & $\begin{array}{l}1.50 \\
(1.1-2.21)\end{array}$ & $\begin{array}{l}1.37 \\
(0.17-2.93)\end{array}$ \\
\hline $\begin{array}{l}\text { PAPP-A } \\
\text { (MoM) }\end{array}$ & $\begin{array}{l}1.06 \\
(0.75-1.46)\end{array}$ & $\begin{array}{l}0.58 \\
(0.4-0.79)\end{array}$ & $\begin{array}{l}0.26 \\
(0.16-0.42)\end{array}$ & $\begin{array}{l}0.37 \\
(0.26-0.56)\end{array}$ & $\begin{array}{l}0.45 \\
(0.27-0.91)\end{array}$ & $\begin{array}{l}0.51 \\
(0.16-1.37)\end{array}$ \\
\hline
\end{tabular}

\begin{tabular}{|lcccccl|}
\hline \multirow{2}{*}{ combined risk } & \multicolumn{7}{c}{ distribution of risks of trisomy according to the karyotype } & & \\
& normal & T21 & T18 & T13 & sex & atypical \\
\hline$>=1$ in $50, \mathrm{n}(\%)$ & $475(2.3)$ & $106(83.5)$ & $31(91.2)$ & $10(76.9)$ & $9(60.0)$ & $16(69.9)$ \\
\hline 1 in $51-1$ in $150, \mathrm{n}(\%)$ & $708(3.4)$ & $7(5.5)$ & $1(2.9)$ & $2(15.4)$ & $2(13.3)$ & $4(17.4)$ \\
\hline 1 in $151-1$ in $250, \mathrm{n}(\%)$ & $630(3.0)$ & $3(2.4)$ & $1(2.9)$ & $0(0)$ & $1(6.7)$ & $0(0)$ \\
\hline 1 in $251-1$ in $500, \mathrm{n}(\%)$ & $1383(6.6)$ & $5(3.9)$ & $0(0)$ & $0(0)$ & $0(0)$ & $1(4.3)$ \\
\hline 1 in $501-1$ in $1000, \mathrm{n}(\%)$ & $2421(11.6)$ & $3(2.3)$ & $1(2.9)$ & $0(0)$ & $2(13.3)$ & $0(0)$ \\
\hline 1 in $1001-1$ in $5000, \mathrm{n}(\%)$ & $10692(51.3)$ & $1(0.8)$ & $0(0)$ & $0(0)$ & $1(6.7)$ & $2(8.7)$ \\
\hline$<1$ in $5000, \mathrm{n}(\%)$ & $4531(21.7)$ & $2(1.6)$ & $0(0)$ & $1(7.7)$ & $0(0)$ & $0(0)$ \\
\hline total & 20840 & 127 & 34 & 13 & 15 & 23 \\
\hline
\end{tabular}

Table 3 Distribution of the risk of trisomy in normal fetuses within fetuses with an abnormal karyotype.
116 (91.3\%), 33 (97.1\%), $12(92.3 \%)$ and 12 (80.0\%) cases with trisomy $21,18,13$ and sex chromosomal abnormalities as well as $20(87.0 \%)$ cases with atypical chromosomal abnormalities. Invasive testing is necessary in 2006 (9.5\%) cases, and 193 (91.0\%) of all chromosomal defects will be detected. The cost of such a screening policy is $21052 \times € 150+2006 \times € 1000=$ $€ 5163800$ or $€ 26755.44$ for each detected aneuploid case.

\section{First trimester combined screening with \\ a cut-off of 1 in 50}

First trimester combined screening with a risk cut-off of 1 in 50 results in 475 (2.3\%) false-positive cases. 106 (83.5\%), 31 (91.2\%), 10 (76.9\%), 9 (60.0\%) and 16 (69.6\%) cases with trisomy 21, 18, 13, sex chromosomal abnormalities and atypical chromosomal abnormalities are detected.

Invasive testing is necessary in 647 (3.1\%) cases, and 172 (81.1\%) of all chromosomal defects can be detected. The cost of such a screening policy is $21052 \times € 150+647 \times € 1000=€ 3804800$, or $€ 22120.93$ for each detected aneuploid case.

\section{Contingent screening with first trimester combined} screening in all women and NIPT in the intermediate risk group (1 in 50 - 1 in 1000)

The high risk group after first trimester combined screening is defined as in policy 2 .

The intermediate risk group consists of 5142 (24.7\%) normal and $33(15.6 \%)$ aneuploid cases. In the normal group, there are 179 abnormal test results following NIPT ( $\mathrm{n}=154$ cases due to uninformative tests and $n=25$ cases with true false-positive results).
Thus, overall, there are 654 (3.1\%) normal fetuses with final high risk test results.

Among the 33 aneuploid cases in the intermediate risk group, NIPT detects 28 (84.8\%).

In total, 200 (94.3\%) aneuploid fetuses are detected: 124 (97.6\%), 34 (100\%), $12(92.3 \%) 14(93.3 \%)$ and 16 (69.6\%) of the cases with trisomy $21,18,13$, sex chromosomal abnormalities and atypical chromosomal abnormalities.

Invasive testing is necessary in $854(4.1 \%)$ cases. The cost of such a screening policy is $21052 \times € 150+5175 \times € 500+854 \times € 1000=$ $€ 6.599 .300$ or $€ 32996.50$ for each detected aneuploid case.

\section{Contingent screening with first trimester combined} screening in all women and NIPT in the intermediate risk group ( 1 in $150-1$ in 500)

The high risk group consists of pregnancies with a sum risk of 1 in 150 or higher involving 1183 (5.7\%), 113 (89.0\%), 32 (94.1\%), 12 (92.3\%), $11(73.3 \%)$ and $20(87.0 \%)$ of the normal fetuses and those with trisomy $21,18,13$, sex chromosomal and atypical chromosomal abnormalities, respectively.

The intermediate group consists of 2013 (9.7\%) normal and 11 (5.2\%) aneuploid cases. In the normal group, there are 70 abnormal test results following NIPT ( $n=60$ cases due to uninformative tests and $n=10$ cases with true false-positive results).

Thus, overall, there are 1253 (6.0\%) normal fetuses with final high risk test results.

Among the 11 aneuploid cases in the intermediate risk group, NIPT detects 10 (90.9\%).

In total, 198 (93.4\%) aneuploid fetuses are detected: 121 (95.3\%), $33(97.1 \%), 12(92.3 \%) 12(80.0 \%)$ and $20(87.0 \%)$ of the cases 
with trisomy $21,18,13$, sex chromosomal and atypical chromosomal abnormalities, respectively.

Invasive testing is necessary in $1451(6.9 \%)$ cases. The cost of such a screening policy is $21052 \times € 150+2024 \times € 500+1451 \times € 1000=$ $€ 5.620 .800$ or $€ 28387.88$ for each detected aneuploid case.

\section{Screening for chromosomal abnormalities by NIPT}

If NIPT is performed in all pregnancies, 115 (0.6\%) normal pregnancies are classified as high risk: 14 cases are due to screen positive results from 625 combined first trimester screening examinations in the group of uninformative NIPT results and 101 cases are due to false-positive results from NIPT.
NIPT detects 126 (99.2\%), 33 (97.1\%),12 (92.2\%) and 15 (100\%) cases of trisomy $21,18,13$ and sex chromosomal abnormalities, respectively, but no $(0 \%)$ cases of atypical chromosomal abnormalities.

In summary, $186(87.7 \%)$ chromosomal abnormalities are detected and 301 (1.4\%) invasive tests are necessary.

The cost of such a screening policy is $21052 \times € 500+625 \times € 150$ $+301 \times € 1000=€ 10920750$ or $€ 58713.71$ for each detected aneuploid case.

Details about each screening policy are given in $\bullet$ Table 4.

\begin{tabular}{|c|c|c|c|}
\hline \multirow{2}{*}{$\begin{array}{l}\text { screening } \\
\text { policies }\end{array}$} & \multicolumn{3}{|c|}{ screen-positive rates, n (\%) } \\
\hline & step 1 & step 2 & total \\
\hline policy 1 & $\begin{array}{l}\text { sum risk > } 1 \text { in } 250 \\
\text { norm: } 1813(8.7 \%) \\
\text { T21: } 116(91.3 \%) \\
\text { T18: } 33(97.1 \%) \\
\text { T13: } 12(92.3 \%) \\
\text { sex: } 12(80.0 \%) \\
\text { atyp: } 20(87.0 \%)\end{array}$ & & $\begin{array}{l}\text { norm: } 1813(8.7 \%) \\
\text { T21: } 116(91.3 \%) \\
\text { T18: } 33(97.1 \%) \\
\text { T13: } 12(92.3 \%) \\
\text { sex: } 12(80.0 \%) \\
\text { atyp: } 20(87.0 \%) \\
\text { total aneuploid: } 193(\mathbf{9 1 . 0} \%) \\
\text { total: } 2006(9.5 \%)\end{array}$ \\
\hline policy 2 & $\begin{array}{l}\text { sum risk >1 in } \mathbf{5 0} \\
\text { Norm: } 475(2.3 \%) \\
\text { T21: } 106(83.5 \%) \\
\text { T18: } 31(91.2 \%) \\
\text { T13: } 10(76.9 \%) \\
\text { sex: } 9(60.0 \%) \\
\text { atyp: } 16(69.6 \%)\end{array}$ & & $\begin{array}{l}\text { norm: } 475(2.3 \%) \\
\text { T21: } 106(83.5 \%) \\
\text { T18: } 31(91.2 \%) \\
\text { T13: } 10(76.9 \%) \\
\text { sex: } 9(60.0 \%) \\
\text { atyp: } 16(69.6 \%) \\
\text { total aneuploid: } 172(81.1 \%) \\
\text { total: } \mathbf{6 4 7}(\mathbf{3 . 1} \%)\end{array}$ \\
\hline policy 3 & $\begin{array}{l}\text { sum risk >1 in } \mathbf{5 0} \\
\text { norm: } 475(2.3 \%) \\
\text { T21: } 106(83.5 \%) \\
\text { T18: } 31(91.2 \%) \\
\text { T13: } 10(76.9 \%) \\
\text { sex: } 9(60.0 \%) \\
\text { atyp: } 16(69.6 \%)\end{array}$ & $\begin{array}{l}\text { NIPT in intermediate risk group } \\
\text { ( } 1 \text { in } 51-1 \text { in 1000) } \\
\text { norm: } 179 \text { of } 5142^{1} \\
\text { T21: } 18 \text { of } 18^{2} \\
\text { T18: } 3 \text { of } 3^{2} \\
\text { T13: } 2 \text { of } 2^{2} \\
\text { sex: } 5 \text { of } 5^{2} \\
\text { atyp: } 0 \text { of } 5^{2}\end{array}$ & $\begin{array}{l}\text { norm: } 654(3.1 \%) \\
\text { T21: } 124(97.6 \%) \\
\text { T18: } 34(100 \%) \\
\text { T13: } 12(92.3 \%) \\
\text { sex: } 14(93.3 \%) \\
\text { atyp: } 16(69.6 \%) \\
\text { total aneuploid: } 200(\mathbf{9 4 . 3} \%) \\
\text { total: } 854(4.1 \%)\end{array}$ \\
\hline policy 4 & $\begin{array}{l}\text { sum risk > } 1 \text { in } \mathbf{1 5 0} \\
\text { norm: } 1183(5.7 \%) \\
\text { T21: } 113(89.0 \%) \\
\text { T18: } 32(94.1 \%) \\
\text { T13: } 12(92.3 \%) \\
\text { sex: } 11(73.3 \%) \\
\text { atyp: } 20(87.0 \%)\end{array}$ & $\begin{array}{l}\text { NIPT in intermediate risk group } \\
(1 \text { in } 151-1 \text { in } 500) \\
\text { norm: } 70 \text { of } 2013^{3} \\
\text { T21: } 8 \text { of } 8^{2} \\
\text { T18: } 1 \text { of } 1^{2} \\
\text { T13: } 0 \text { of } 0^{2} \\
\text { sex: } 1 \text { of } 1^{2} \\
\text { atyp: } 0 \text { of } 1^{2}\end{array}$ & $\begin{array}{l}\text { norm: } 1253(6.0 \%) \\
\text { T21: } 121(95.3 \%) \\
\text { T18: } 33(97.1 \%) \\
\text { T13: } 12(92.3 \%) \\
\text { sex: } 12(80.0 \%) \\
\text { atyp: } 20(87.0 \%) \\
\text { total aneuploid: } 198(93.4 \%) \\
\text { total: } 1451(6.9 \%)\end{array}$ \\
\hline policy 5 & $\begin{array}{l}\text { NIPT in all cases } \\
\text { norm: } 115(0.6 \%)^{4} \\
\text { T21: } 126(99.2 \%)^{2} \\
\text { T18: } 33(97.1 \%)^{2} \\
\text { T13: } 12(92.2 \%)^{2} \\
\text { sex: } 15(100 \%)^{2} \\
\text { atyp: } 0(0 \%)^{2}\end{array}$ & & $\begin{array}{l}\text { norm: } 115(0.6 \%) \\
\text { T21: } 126(99.2 \%) \\
\text { T18: } 33(97.1 \%) \\
\text { T13: } 12(92.3 \%) \\
\text { sex: } 15(100 \%) \\
\text { atyp: } 0(0 \%) \\
\text { total aneuploid: } 186(\mathbf{8 7 . 7} \%) \\
\text { total: } \mathbf{3 0 1}(\mathbf{1 . 4} \%)\end{array}$ \\
\hline
\end{tabular}

Table 4 Screen-positive rates according to the screening policy.

Norm = normal cases, $\mathrm{T} 21 / 18 / 13=$ trisomies 21/18/13, Sex $=$ sex chromosomal aneuploidies, Atyp = atypical chromosomal abnormalities.

$15142(24.7 \%)$ normal cases have a sum risk between 1 in 51 and 1 in 1000. In this group, NIPT is carried out with 179 abnormal test results: $3.0 \%$ are uninformative corresponding to 154 cases. In the remaining 4988 cases, the false-positive rate with NIPT is $0.5 \%$, which corresponds to 25 false-positive cases.

${ }^{2}$ For trisomy $21,18,13$ and sex aneuploidy, it was assumed that detection rates of NIPT are $99 \%, 98 \%, 90 \%$ and $99 \%$. The number of cases is rounded to the nearest whole number.

${ }^{3} 2013$ (9.7\%) normal cases have a sum risk between 1 in 151 and 1 in 500 . In this group, NIPT is carried out with 70 abnormal test results: $3.0 \%$ are uninformative corresponding to 60 cases. In the remaining 1953 cases, the false-positive rate with NIPT is $0.5 \%$, which corresponds to 10 false-positive cases.

${ }^{4}$ NIPT is carried out in all patients with 3\% uninformative results corresponding to 625 cases. In this group first trimester combined screening is performed with a sum risk cut-off of 1:50 and a false-positive rate of $2.3 \%$. This corresponds to 14 false-positive cases. In the remaining 20215 normal cases, NIPT would be carried out with a false-positive rate of $0.5 \%$, which corresponds to 101 cases. 


\section{Discussion}

\section{$\nabla$}

In this paper we have shown that firstly, trisomy 21 accounts for about $60 \%$ of all chromosomal abnormalities, and secondly, about $10 \%$ of atypical chromosomal abnormalities are associated with an adverse outcome that cannot be identified by common NIPT programs.

Policy 5 (first line screening with NIPT) provided the highest trisomy 21 detection rate and the lowest invasive testing rate.

However, this approach requires that NIPT be done within a limited time frame of about 10 weeks so that there is still enough time to carry out first trimester combined screening if NIPT is uninformative. In addition, such a screening policy is associated with the highest costs.

Focusing on the detection of all chromosomal abnormalities, the contingent screening policies (policy 3 and 4) were most favorable, with detection rates of $93-94 \%$. The costs of both contingent screening approaches were substantially lower than with policy 5 (first line screening with NIPT) and only moderately higher than with policy 1 (first trimester screening with a risk cut-off of $1: 250)$. The latter approach results in detection rates of $91 \%$ of all chromosomal abnormalities but in an expense of an invasive testing rate of almost $10 \%$. This is partly due to the shift in the maternal age distribution towards older women in our study population. The advantage of such a policy relies in the small number of missed cases with atypical chromosomal abnormalities. Only 3 of the 23 cases remained undetected. In contrast, the "NIPT only" approach missed all of these cases.

Within this group, there were 9 cases of triploidy, which are potentially detectable by an NIPT program based on a feto-parental comparison of polymorphisms [18]. At least some of these rare chromosomal abnormalities could have been picked up by a careful early anomaly scan due to the increased prevalence of major anomalies [19]. However, first trimester assessment of the fetal anatomy is not as standardized as the NT measurement and is highly dependent on the expertise of the operator.

The majority of these cases with atypical chromosomal abnormalities have an increased sum risk for trisomy due to increased NT or abnormal biochemical marker levels. Therefore, it seems reasonable to recommend karyotyping if the risk after first trimester combined screening surpasses a certain threshold, and to restrict NIPT to the intermediate risk group. They may become even more evident, if in all high risk cases CGH array analysis is done [20, 21]. It could be argued that it is unnecessary to focus on these rare and lethal chromosomal abnormalities. However, as some of them, for example diandric triploidy, can result in very early preeclampsia, and as maternal morbidity and mortality are increased in late termination of pregnancy, early identification of these pregnancies is still beneficial [22, 23].

Our results are consistent with previous studies. Cuckle et al. recently performed a cost sensitivity analysis for NIPT screening programs [24]. With a screening policy that only relies on NIPT and costs of $\$ 1000$ for karyotyping and $\$ 500$ for NIPT, the authors estimated that the average cost per Down syndrome detected (or according to their authors "avoided") compared with first trimester combined screening was $\$ 383000$. They concluded that a contingent policy in which $10 \%$ to $20 \%$ of women were selected for NIPT after first trimester combined screening was considerably more cost-efficient.

We acknowledge that our study contains some weaknesses. In our study, the median maternal age was 35 years, in contrast to 30.7 years in Germany [25]. However, the observed maternal age distribution among the 21052 examined pregnancies is representative for women requesting first trimester screening in Germany. Thus, our results are more realistic for Germany than after adjusting for maternal age.

We only included data on fetuses that were born at least a year ago to allow sufficient time for postnatal follow-up examinations. We therefore believe that we have identified all live born children with major chromosomal abnormalities. However, due to the retrospective character of our study, karyotyping was not performed in cases with intrauterine demise, although there is an increased risk for aneuploidy in these cases [26]. We also believe that we may have underestimated the proportion of fetuses with balanced rearrangements, as postnatal karyotyping was only performed in suspicious cases. However, as we would have grouped these cases together with the euploid group in any case, the overall results of our study are not affected.

In contrast to the first trimester combined screening results, we had to estimate the performance of NIPT. We tried to apply realistic figures for the detection and false-positive rates, but so far prospective screening studies about NIPT have involved only a limited number of cases. Nicolaides et al. reported on a screening study with 1939 euploid fetuses and 8 with trisomy 21. The detection rate was $100 \%$, with a false-positive rate of $0 \%$ [27]. Song et al. observed the same screening performance in a study involving 8 trisomy 21 and 1733 pregnancies [28]. In the largest study, Dan et al. examined NIPT in 10916 euploid pregnancies and 139 with trisomy 21 [29]. There was one false-positive case, and all affected fetuses were identified. In terms of trisomy 18 and 13, there is even less evidence. In the studies by Palomaki, Norton and Ashoor, $98.6 \%$ of the pooled 147 fetuses with trisomy 18 were found. The false-positive rate was $0.1 \%$ [30 - 32]. Palomaki and Ashoor reported on 22 cases with trisomy 13 and a detection rate of $86.4 \%$, with a false-positive rate of $0.5 \%$ [30, 33]. In terms of sex chromosome abnormalities, Mazloom et al. demonstrated that in their study with 19 gonosomal abnormalities, all affected cases were identified. An abnormal karyotype was suspected in $0.3 \%$ of the 1450 normal cases [34]. When larger studies about NIPT become available, the screening performance of NIPT will fall slightly, for example due to a mosaic karyotype.

The test will remain uninformative in about $3 \%$ of all NIPT examinations [17]. This is due to low fetal fraction in maternal plasma cell-free DNA. At $11-13$ weeks of gestation, the median fraction is about $10 \%$ and at least $4 \%$ are required for successful NIPT examinations. Fetal fraction decreases with maternal weight, increases with fetal CRL, maternal serum level of free beta-hCG and PAPP-A, and is higher in smokers and in the fetuses with trisomy 21 . The greatest contribution to fetal fraction, however, is provided by maternal weight. For example, the estimated proportion with fetal fraction below $4 \%$ increases from $0.7 \%$ at $60 \mathrm{~kg}$ to $7.1 \%$ at $100 \mathrm{~kg}$ and $51.1 \%$ at $160 \mathrm{~kg}$. The inverse association between fetal fraction and maternal weight is mostly attributed to dilutional effects, but could also be explained by an accelerated turnover of adipocytes, which releases an increased amount of cell free DNA of maternal origin into the circulation, resulting in a lower fetal proportion of cell free DNA.

In summary, we have shown that contingent screening with first trimester combined testing for all women and NIPT in the intermediate risk group provides higher detection rates than first trimester combined screening or NIPT alone. 


\section{Literature}

1 Kagan KO, Etchegaray A, Zhou Y et al. Prospective validation of first-trimester combined screening for trisomy 21. Ultrasound Obstet Gynecol 2009; 34: $14-18$

2 Kagan KO, Wright D, Baker A et al. Screening for trisomy 21 by maternal age, fetal nuchal translucency thickness, free beta-human chorionic gonadotropin and pregnancy-associated plasma protein-A. Ultrasound Obstet Gynecol 2008; 31: 618-624

3 Merz E, Thode C, Eiben B et al. Individualized correction for maternal weight in calculating the risk of chromosomal abnormalities with first-trimester screening data. Ultraschall in Med 2011; 32: 33 - 39

4 Kagan KO, Eiben B, Kozlowski P. Kombiniertes Ersttrimesterscreening und zellfreie fetale DNA - "Next Generation Screening". Ultraschall in Med 2014; 35 (3): 229-236

5 Benn P, Cuckle H, Pergament E. Non-invasive prenatal testing for aneuploidy: current status and future prospects. Ultrasound Obstet Gynecol 2013; 42: $15-33$

6 Tercanli S, Vial Y, Merz E. Nicht invasiver Chromosomentest wirft neue Fragen in der Pränataldiagnostik nach der Bedeutung des Ultraschalls und Fragen nach neuen Screeningstrategien auf. Ultraschall in Med 2013; $34: 417-420$

7 Eiben B, Thode C, Merz E. Nichtinvasive Pränataldiagnostik Serumtestsysteme zur Erfassung von Chromosomenanomalien. Gynäkologie+ Geburtshilfe 2013; 18: 34-37

8 Eiben B, Glaubitz R, Merz E. Trisomie-21-Analyse aus mütterlichem Blut. frauenarzt.de 2012; 53: $834-835$

9 Kagan K, Hoopmann M, Kozlowski P. Assessment of Foetal DNA in Maternal Blood - A Useful Tool in the Hands of Prenatal Specialists. Geburtsh Frauenheilk 2012; 72: 998 - 1003

10 Nicolaides $K H$, Wright $D$, Poon LC et al. First-trimester contingent screening for trisomy 21 by biomarkers and maternal blood cell-free DNA testing. Ultrasound Obstet Gynecol 2013; 42: 41 - 50

11 Grati FR, Barlocco A, Grimi B et al. Chromosome abnormalities investigated by non-invasive prenatal testing account for approximately $50 \%$ of fetal unbalances associated with relevant clinical phenotypes. Am J Med Genet 2010; 152A: 1434-1442

12 Wright D, Kagan KO, Molina FS et al. A mixture model of nuchal translucency thickness in screening for chromosomal defects. Ultrasound Obstet Gynecol 2008; 31: 376-383

13 Wright D, Spencer K, Kagan KK et al. First-trimester combined screening for trisomy 21 at 7-14 weeks' gestation. Ultrasound Obstet Gynecol 2010; 36: 404-411

14 Cuckle HS, Wald NJ, Thompson SG. Estimating a woman"s risk of having a pregnancy associated with Down"s syndrome using her age and serum alpha-fetoprotein level. Br J Obstet Gynaecol 1987; 94: 387 - 402

15 Snijders RJ, Sundberg K, Holzgreve $W$ et al. Maternal age- and gestation-specific risk for trisomy 21. Ultrasound Obstet Gynecol 1999; 13: $167-170$

16 Kagan KO, Wright D, Spencer K et al. First-trimester screening for trisomy 21 by free beta-human chorionic gonadotropin and pregnancyassociated plasma protein-A: impact of maternal and pregnancy characteristics. Ultrasound Obstet Gynecol 2008; 31: 493-502

17 Gil MM, Akolekar R, Quezada MS et al. Analysis of Cell-Free DNA in Maternal Blood in Screening for Aneuploidies: Meta-Analysis. Fetal Diagn Ther 2014
18 Nicolaides KH, Syngelaki A, Del MarGil M et al. Prenatal Detection of Fetal Triploidy from Cell-Free DNA Testing in Maternal Blood. Fetal Diagn Ther 2013, accepted.

19 Syngelaki A, Chelemen T, Dagklis T et al. Challenges in the diagnosis of fetal non-chromosomal abnormalities at 11-13 weeks. Prenat Diagn 2011; 31: $90-102$

20 Leung TY, Vogel I, Lau TK et al. Identification of submicroscopic chromosomal aberrations in fetuses with increased nuchal translucency and apparently normal karyotype. Ultrasound Obstet Gynecol 2011; 38: $314-319$

21 Wapner RJ, Martin CL, Levy B et al. Chromosomal microarray versus karyotyping for prenatal diagnosis. N Engl J Med 2012; 367: 2175 2184

22 Rijhsinghani A, Yankowitz J, Strauss RA et al. Risk of preeclampsia in second-trimester triploid pregnancies. Obstet Gynecol 1997; 90: $884-888$

23 Bartlett LA, Berg CJ, Shulman HB et al. Risk factors for legal induced abortion-related mortality in the United States. Obstet Gynecol 2004; 103: $729-737$

24 Cuckle H, Benn P, Pergament E. Maternal cfDNA screening for Down syndrome - a cost sensitivity analysis. Prenat Diagn 2013; 33: 636 642

25 GeburtenMutterBiologischesAlter.html. Available from: https://www. destatis.de/DE/ZahlenFakten/GesellschaftStaat/Bevoelkerung/ Geburten/Tabellen/GeburtenMutterBiologischesAlter.html Accessed on: 1.12.2013

26 Lathi RB, Gray Hazard FK, Heerema-McKenney A et al. First trimester miscarriage evaluation. Semin Reprod Med 2011; 29: 463 - 469

27 Nicolaides KH, Syngelaki A, Ashoor G et al. Noninvasive prenatal testing for fetal trisomies in a routinely screened first-trimester population. Am J Obstet Gynecol 2012; 207: 374.e1 - 374.e6

28 Song Y, Liu C, Qi H et al. Noninvasive prenatal testing of fetal aneuploidies by massively parallel sequencing in a prospective Chinese population. Prenat Diagn 2013; 33: 700-706

29 Dan S, Wang W, Ren J et al. Clinical application of massively parallel sequencing-based prenatal noninvasive fetal trisomy test for trisomies 21 and 18 in 11105 pregnancies with mixed risk factors. Prenat Diagn 2012; 32 : 1225 - 1232

30 Palomaki GE, Deciu C, Kloza EM et al. DNA sequencing of maternal plasma reliably identifies trisomy 18 and trisomy 13 as well as Down syndrome: an international collaborative study. Genet Med 2012; 14 : 296- 305

31 Ashoor G, Syngelaki A, Wagner $M$ et al. Chromosome-selective sequencing of maternal plasma cell-free DNA for first-trimester detection of trisomy 21 and trisomy 18. Am J Obstet Gynecol 2012; 206: 322.e1 322.e5

32 Norton ME, Brar H, Weiss J et al. Non-Invasive Chromosomal Evaluation (NICE) Study: results of a multicenter prospective cohort study for detection of fetal trisomy 21 and trisomy 18. Am J Obstet Gynecol 2012; 207: 137.e1 - 137.e8

33 Ashoor G, Syngelaki A, Wang E et al. Trisomy 13 detection in the first trimester of pregnancy using a chromosome-selective cell-free DNA analysis method. Ultrasound Obstet Gynecol 2013; 41: 21 - 25

34 Mazloom AR, Džakula Z, Oeth $P$ et al. Noninvasive prenatal detection of sex chromosomal aneuploidies by sequencing circulating cell-free DNA from maternal plasma. Prenat Diagn 2013; 33: 591 - 597 